\title{
Practical theology and narrative: Contours and markers
}

\author{
Klaasen, John \\ University of the Western Cape \\ jsklaasen@uwc.ac.za
}

\begin{abstract}
There has been a definite turn in practical theology and theology at large in the last four decades. The inadequacies of the Enlightenment project to keep in tension the rational and non-rational traditions of interpretations, significance of the relative for universal moral appropriation, the importance of lived experiences for identity, the critical engagement of tradition and choice, and the widening gap between the finite and infinite are addressed within a narrative approach. Another voice is added to narrative approaches for the interpretation of person, the world and God. Narrative approach for meaning making of person, world and God through reasoning is embedded in experience.

A common thread of narrative theology is that persons can make sense of themselves, the world and God through stories. A narrative approach to theology is much more than a bridge between interpretation and first order language. It is the process, structure, and form of interpretation and reflection of the experience, activities, and communication of the Christian community through stories. An open ended narrative approach engages critically with constants such as reason, particularity, history, community and experience.

A brief overview of narrative within theology and within practical theology in particular is followed by a historical overview of the development of the use of narrative. An open ended narrative with specific characteristics makes up the main components of the article.
\end{abstract}

\section{Key words}

Narrative; practical theology; experience; community; open ended 


\section{Introduction}

There has been a definite turn in practical theology and theology at large in the last four decades. This turn has been an attempt to address the inadequacies of the Enlightenment project to keep in tension the rational and non-rational traditions of interpretations, significance of the relative for universal moral appropriation, the importance of lived experiences for identity, the critical engagement of tradition and choice, and the widening gap between the finite and infinite. 'Who we are' is more a question of philosophical formulation than continuous practical involvement in common existence through relationships. It is more about how much you know than about taking responsibility. Independence instead of dependence has become the form of identity. The laws of logic are in the degree of abstraction and not the linguistic and cultural structure of the community. Universality has stripped tradition of its authority and pushed it to the periphery, where spectators are plenty, but substance inconsequential.

The role of theology to address the inadequacies mentioned above has caused doubt about the early creedal formulations and confessions as the source of Christian identity in the political and social landscape, where divinity is far less acknowledged when compared to the pre-modern era. The systematic theology approach to interpret the world, individual and God, and critical reflection on first order language has come under severe scrutiny because of its failure to address some of the shortcomings of the modern world.

The black theologian, James Cone, clearly opposes the traditional systematic theology approach when he states the following:

If someone asks me, Jim, how can you believe? What is the evidence of truth? My reply is quite similar to the testimonies of the Fathers and Mothers of the Black Church: let me tell you a story about a man called Jesus who was born in a stable in Bethlehem ... He went throughout ... Galilee preaching that the Kingdom is coming, repent and believe the gospel. The Kingdom is the new creation where the hungry are fed, the sick healed and the oppressed liberated. It is the restoration of humanity to its wholeness. This man Jesus was killed because of his threat to the order of injustice. But he was resurrected 
as Lord, thereby making good God's promise to bring freedom to all who are weak and helpless ... I was told this story by my mother and father. They told this story as the truth of their lives, the foundation of their struggle. I came to know this story as the truth in my own struggle in situations of trouble. Jesus is now my story, which sustains and holds me together in struggle. I cannot and have no desire to prove my story. All I can hope or wish to do is to bear witness to it, as this story leads me to openness to other stories (1975:116-119).

Cone falls within a long list of contemporary theologians from both the North and the South who seek to engage critically with the dominant approaches of theology and specifically, systematic theology. Cone and others, those associated with the German and Yale approaches, have brought the notions of story within the centre of theological reflection. Instead of abstract reason, universalism and individualism, a narrative approach includes non-rational tradition (symbols and myth), particular lived experience, and the self as person.

It is not my intention to question the systematic theology approaches for the interpretation of person, the world and God. I would like to add my voice to the many theologians who have developed narrative theology in the last forty years in order to give meaning to personhood, revelation, and the cosmos. In my case, I would like to explore a narrative approach for meaning making of person, world and God through reasoning that is embedded in experience. This does not mean that my approach to meaning making of self, world and God is uniquely narrative, but that experience is more integral to reason than the postconstructionalist (Müller) and correlation (Browning) approaches. I will point out a number of the weaknesses of some of the narrative approaches used in practical theology and add a few markers.

Narrative theology has taken many forms and shapes, but there is a common thread throughout. The common thread has at times been viewed as antagonistic with confessional forms of theology, at times as "propaedeutic to, what Teselle calls a kind of 'intermediary or parabolic" (Stroup 1984:85). At times, narrative theology has also been regarded as the source of the raw material (Dietrich Ritschl) that the theologian uses 
to reflect upon and make judgements about doctrines and confessions. The common thread of narrative theology is that persons can make sense of themselves, the world and God through stories. A narrative approach to theology is much more than a bridge between interpretation and first order language. It is the process, structure, and form of interpretation and reflection of the experience, activities, and communication of the Christian community through stories.

\section{Forms of narrative theology}

Stroup divides the literature of narrative theology into three categories; theology as introduction to religion, the experiential root of narrative, and biblical narrative. The first can be associated with Dietrich Ritschl, ${ }^{1}$ Harald Weinrich, Johann Baptist Metz and Hans Frei. ${ }^{2}$ The German discussion has focussed on the narrative and doctrinal or systematic theology. The question is whether theology is best done in discursive arguments or in the form of personal or communal stories as a more intelligible approach? The German approach also uses narrative to reinterpret the traditional doctrines and creeds of the church. Is the Trinity best appropriated through abstract reason and universal principles, or does tradition and situation make the doctrine of Trinity epistemological and relevant for twenty-first century Christians?

One can ask if discursive arguments or doctrinal formulations give a real description of reality or whether it is narrative that best describes reality. Metz, the German theologian who has probably done the most to establish narrative theology in Germany, asserts that the German people should hear the story of the suffering of Jesus and the suffering of the victims in history to make sense of the present suffering in the world. ${ }^{3}$

1 Dietrich Ritschl has produced the most comprehensive discussion of narrative as an introduction to religion and addresses the relationship between narrative and human identity, the form, nature and function of story, and the relationship between story and theology. For a discussion of this, see G. Stroup (1981:74).

2 Hans Frei cannot be limited to one dimension of narrative theology. He is also regarded as one of the foremost influential theologians for whom Scripture forms the basis of narrative theology.

3 Smit tells the story of the well-known South African anti-Apartheid activist and theologian who actively and concretely understood and participated in the suffering of oppressed people (Smit 1990:114-115). 
Secondly, the so-called Yale approach is widely regarded as the initiator of what is sometimes referred to as the postliberal approach to theology. James McClendon $\mathrm{Jr}^{4}$., Stanley Hauerwas ${ }^{5}$ (and John Yoder, who together with MacIntyre was probably the single most significant influence on Hauerwas's narrative ethics and theology) and John Dunne, ${ }^{6}$ also focus on the experience of humans in relation to God and the role of narrative in moral formation. Narrative theology is sometimes referred to as postliberal theology because it engages critically with the foundations of modernity.

An important dimension of narrative, and the difference between the socalled German approach and the Yale approach, is that it does not only provide structure for understanding reality, but this second approach also addresses the significance of understanding reality through narrative for character formation and moral actions. This approach has more to do with being or who I am than knowing or what I know.

Hauerwas is considered a leading proponent of this second category of narrative scholars. He is critical of the foundations of the modern project and dismisses the Kantian categorical approach to ethics. For Hauerwas, a narrative approach takes the particular as normative for the universal. It is not abstract principles, but rather embeddedness within a tradition and community that gives structure to narrative. It is not any community and any tradition within which the narrative has meaning, but the Christian church as community and the world makes sense of reality through the history of the church, which is also the history of the world.

4 McClendon, J.W. Jr., and Smith, J.M., Understanding religious convictions. McClendon and Smith justify religious utterances and convictions on the basis of linguistic usage familiar to the hearer and speaker, the description of the relevant reality, and affective conditions. For a more detailed discussion, see Goldberg (1982:196-240).

5 Hauerwas uses story as an explanation of character and description of the intentionality of actions. See Hauerwas, S., Bondi, R. and Burrell, D.B., (1977) Truthfulness and Tragedy, University of Notre Dame Press, Notre Dame, Indiana (1977:75-76); Hauerwas, S., (1975) Character and the Christian life: A study in theological ethics, and Hauerwas, S. (1974) Vision and Virtue: Essays in Christian ethical reflection, Notre Dame, Fides. For a discussion of Hauerwas's use of story for character formation, see Klaasen (2008:129137).

6 Dunne introduces a method, "passing over" and the heuristic use of biography and autobiography to enter into others stories. One then comes to new understandings of oneself. For a discussion of the relationship between human experience, God's time and identity, see Stroup (1981:77-78). 
The Christian narrative is normative for truth and freedom. Within this form of narrative theology, the clearest breakaway from modernity is found. The law finds meaning within narrative and more damning within a specific narrative. Individuals are not autonomous, determined by the degree of independence, but by their placement within a community. Although Hauerwas rejects fideism, abstract reason has very little role to play in this second approach.

Is this second approach to narrative a desperate attempt to make theology relevant in the world where the Kantian categorical imperative has occupied the main and determinant space on the stage? In other words, can it be that the exclusive approach of narrative theology takes the form of rivalry in order to claim its dominant position as meta-narrative? Lucie-Smith points out that Gustafson accused Hauerwas of representing "the sectarian temptation: instead of trying to seek aggiornamento, which could lead to a dilution of the tradition, he has instead chosen to retreat into tradition, where he can retain his certainties. He has chosen to make the narrative normative, but by what criteria is such a narrative chosen?" (2007:45).

This second approach to narrative theology increases the distance between the modern project and the narrative approach. The difference between narrative and dogma, church and culture, law and tradition, individual and community is too far for any meaningful dialogical conversation to take place. The distance or exclusiveness influences the structure (particular), scope (limited), and form (specific) of the narrative. One can question the foundationalist approach of Hauerwas, which he himself accuses modernity of.

The third type of narrative theology is biblical narrative. Frei and Sallie McFague represent a long list of theologians who focus on the structure of Scripture (including the Gospels and parables) (Stroup 1981). ${ }^{7}$ Frei, who is greatly influenced by Karl Barth, made some of the most significant contributions in The identity of Jesus Christ and The eclipse of Biblical

7 Goldberg, M., provides a useful overview of narrative theologians in Theology and Narrative: A critical introduction, Nashville: Abington Press (1982). He gives an overview of various theologians who concern themselves with narrative in each of the chapters. In so doing, he gives an insightful analysis of various ways of how narrative is used by a diverse number of theologians and philosophers. 
narrative. Within this third category of narrative theologians, the structure of a good narrative resonates with the structure of human experience (Goldberg 1981:164).

Frei's resurgence of narrative was to counter the unrealistic reality that was caused by theologians who separated truth from meaning. Here we can mention Locke, Schleiermacher, Ritschl, Brunner, Bultmann, Rahner, Pannenberg, and Moltmann. For Frei, the biblical narrative is both reality and meaning. Frei, a literary theorist, emphasises the narrative nature of the biblical texts and opposes the reduction of the texts to rational and universal truth claims. In response to one of Carl Henry's lectures, Frei asserts that:

If by a miracle of divine grace I should get to heaven, I am going to listen in on a conversation that I am going to request among Wilfred Sellars, Alvin Plantinga, Willard Quine, John Stuart Mill, Immanuel Kant, and Aristotle. I am going to listen in, and when they agree on what they mean by logic, and when they agree on the transcendental categories that get them started on their way to formal certainty and clarity, and on their epistemologies or lack of them, then I'll have a starting point for a natural theology ... But until then, that's my problem ... I proceed on the conviction that there is genuine continuity in the language of the Christian church as it readapts itself in every age of the paradigmatic language of Scripture, particularly to the story of the gospel and to reading the OT as the 'figure' leading toward fulfilment in that story (Hunsinger and Placher 1993:210).

We find in the above creative account critical engagement between modernism and postmodernism. Reyneke summarises modernism as 'emphasised human intellectual ability and had faith in technology and science to produce utopia. There is confidence in knowledge, objectivity is both desirable and possible; foundationalism is the model for knowledge; individual knower is the model of the knowing process and the structure of reality is rational' (2005). Postmodernism, on the other hand, has to do with non-rational discourses, culturally informed knowledge, and is context laden and language bound (O’ Donnell 2003:6). 
Sallie McFague is less abstract and more pragmatic about biblical narrative. McFague forms part of the Yale group of theologians and biblical scholars who "has focussed attention neither on the canon nor the narrative structure of the Gospels but on the parable. Parables, they argue, are a form of narrative and when understood as metaphors they show us how Christian narrative in its different forms (poetry, novel, and autobiography) functions" (Stroup 1981:83). The emphasis is not the historical dimension, but the structure of the narrative for seeing reality. "... she claims that the structure displayed by parables furnishes the basis for all Christianand indeed all human-understanding of God, self and world" (Goldberg 1982:162). Humanity reasons by means of metaphor and it is only within metaphorical structure that we see the world for what it really is. Reality is reality in metaphor. Metaphor possesses that deeper dimension that uncovers what is real in such a way that we are able to see the future in the here and now.

Stroup cautions against making parable the primary genre in the New Testament. He claims that the parables are not 'self-contained', but open to the variety of interpretations that is popular at any given time. He further asserts that parables have no connection with historical events if they are taken in isolation. The Christian faith clearly is not ahistorical and therefore parables, a genre that is ahistorical, is incompatible with Christian faith (1981:83-84).

Despite the difference in structure, form and scope, there are some definite correlations across the three forms of narrative. Narrative theology forces systematic theology to re-evaluate the effectiveness of the privileged position of traditional systematic theology. Immigration, sexuality, poverty, and the environmental crisis have asked serious questions of traditional formulations of doctrines such as the Trinity, Holy Spirit, Personhood, Ecclesiology, and God.

The narrative project gives structure to the world and meaning to chaos and formlessness. Story, like social constructionism, is relativistic, but not enslaved by relativism. Within each situation and context, narrative forms and even gives meaning to identity. I contend with Stroup that "Narrative is an important theological category because it is essential for understanding human identity and what happens to the identity of persons in that process Christians describe by means of the doctrine of revelation' (1981:70-89). 
Narrative theology confronts the fundamentals of modernity. Individualism, abstract rationality and universal principles are confronted with phenomena such as community, non-rational tradition and tradition. Narrative theology draws on a greater role of collectivity, constructive reasoning, and contextuality.

\section{Narrative and practical theology}

Narrative approaches have become important in practical theology in the last two decades where narrative is used in a broad spectrum within practical theology. Narrative is used in practical ministry and communication, including preaching and pastoral care. Here we can include David Buttrick, Eugene Lowrey, John Wright, and Cas Vos. Narrative in pastoral care is associated with scholars such as Charles Gerkin, Chris Schlauch, Andrew Lester, and Julian Müller. Narrative theology is also used in empirical analysis of religious significance within social settings and "deconstruction of religious subjectivity that is inherent to narrative". Here we can identify Anderson and Foley (worship), Thomas Groome (Christian education) Heinz Streip (faith development), and James Hopewell (congregational studies) (Ganzevoort 2012:218-219).

Müller's pastoral care model represents an evolving model that is rooted in the dimensions of the turn in practical theology during the 1990's. There is a continuum within his narrative approach to narrative theology as he seeks to interpret the transitions of the twentieth-first century world and how humanity relates to contexts in transition. Like most narrative theologians, Müller started off by adding a prefix to the hermeneutical concept. This is a shift away from systematic, abstract and theoretical approaches to theology. "This approach, although also hermeneutical in nature, moves beyond mere hermeneutics. It is more reflexive and situational embedded in epistemology" (Müller 2011:3).

Towards the end of the twentieth century Müller was influenced by the social constructionist paradigm. The underlying current of social phenomena both shapes and forms identity and reality. Sung Kyu Park, a student of Müller, describes social constructionism as "a postmodern project, is seen as an alternative to modernist faith in the individual mind, rationality, objectivity and truth. This is a shift from focussing on the 
process by an individual person who constructs a model of reality from his or her individual experience, towards focusing on the way in which people interact with one another to construct, modify and maintain what society holds to be true, real and meaningful" (2010:5). Social constructionism became important as far as practical theological collaborations with the social and human sciences are concerned. Social constructionism did not form such an integral part of Müller's approach as it did in the approach of feminist theologians such as Rosemary Radford Ruether, Dorothee Sölle and Rebecca Chopp (Radford Ruether' student). In feminist theology, social constructionism became a means of formation and identity within theology or in interdisciplinary methodologies.

In a second contour, Müller's model of narrative theology developed from social constructionism to postfoundationalism. Influenced by Wentzel van Huyssteen's postfoundational theology, Müller develops a post foundationalism approach ${ }^{8}$ of practical theology. Müller developments Van Huyssteen's approach in a seven movements approach. Firstly, a description is made of a specific context that refers to the actual affected persons and their actual experiences. Secondly, in-context experiences are listened to. Stories are told by all the participants and careful attention is given to all aspects of the experience. Listening is a deliberate tool of clarifying the narrated experiences. Thirdly, interpretations of experiences are made, described and developed in collaboration with co-researches. In this moment, the researcher is not only interested in the theoretical interpretations of the narratives, but also the meaning attached by the coresearches to the narrated experience. Fourthly, a description of experiences is given as it is informed by traditions of interpretation. The experiences and narration thereof is connected to certain traditions and cultures, which must be taken cognizance of for a more holistic understanding of the narratives. Fifthly, the religious and spiritual aspects are reflected on without any enforced perceptions. Notions of the Ultimate Being are to be understood as confessed and proclaimed in the specific situations. Sixthly, a description of experience, which is thickened through interdisciplinary

8 Sung Kyu Park, a former student of Julian Muller, provides an interesting discussion of social-constructionism and post foundationalism in Park, S-K., 'A postfoundationalist research paradigm of practical theology' HTS Teologiese Studies/Theological Studies 66(2), Art.\#849, 6 pages. 
investigation, deepens the understanding of the experience. Finally, the alternative interpretations are developed at that point beyond the community towards other communities (2004:304). This approach derives from the locality of experience and dialogical movement between tradition and context (Müller 2004:304).

\section{Rationality as socially constructed}

In a clear move away from the traditional systematic theology approaches, Müller opts for a rationality that is not abstract, but socially embedded. Rationality is not completely objective, but within the socio-cultural context of the community. Drawing from Van Hyussteen's post foundational theology, Müller opts for transversal rationality. Transversal rationality attempts to overcome the limitations of both the foundational universal truths and the non-foundational absolute diversification of rationality. "Transversal rationality is a concept that was formulated by scholars such as Schrag and Van Huyssteen. It is an attempt to envision a responsible and workable, tangent point between disciplines". Müller continues by quoting Van Huyssteen: "In this multidisciplinary use of the concept of transversality there emerge distinct characteristics or features: the dynamics of consciousness, then interweaving of many voices, the interplay of social practices are all expressed in a metaphor that points to a sense of transition, lying across, extending over, intersecting, meeting, and conveying without becoming identical"9 (2011:3).

Transversal rationality can be metaphorically depicted as a holding space for multidiscipline rational engagement without the threat of domination or exclusion. All disciplines are valued as legitimate processes of authoritative cognitive engagement with openness towards self-critical reflection. There is a contact point between and amongst the different disciplines without compromising the essence of the various disciplines. The contact point can be commonalities of methodology, similarity in form or structure.

Additionally, transversal rationality seems to be that moment of space whereby different disciplines enrich each other through different

9 This quote is taken by Muller from Van Huyssteen, J.W., 2006a, Alone in the world? Human uniqueness in science and theology, The Gifford lectures, W.E. Eerdmans Publishers, Grand Rapids, MI. 
methodologies and deeper understandings. This kind of rationality provides convergence for commonality of different beliefs and meanings of different cultures (Park 2010:2).

Transversal rationality runs the risk of being submerged in the complexity of interdisciplinary dialogue. This use of reason for a narrative approach to theology can lose its credibility if it does not revert back to the context within which the narrative has its root. Certain disciplines within both the social sciences and human sciences borders on abstract rationality and find interdisciplinary work plausible if it is principle and not contextual based. Unless narrative theology returns to the context, its engagement with other disciplines will be self-destructive.

Narrative practical theology is a recognised and accepted discipline with epistemologies that has equal status with other disciplines. Reason is embedded in the social and cultural contexts of the persons. These persons are not only restricted to the academic scholars or professional practical theologians, but also includes the persons who tell their stories. Those who tell their stories are referred to as 'co-researches' because they have as much authority as the professional theologian in both the subject and method of research. Dreyer, who places Müller in the metaphorical approaches in the human and social sciences, asserts that Muller's approach is "humancentred and participatory".

According to Dreyer, Müller's approach is also characterised by a high level of ethics. The approach guards against the misuse of power relations amongst all participants in the research process. Dreyer also warns to guard against the overemphasis of the ontological claim that identity and personhood be reduced to narrative. This is the same limitation that Hauerwas is guilty of when he reduced persons to 'aliens in the household of God'. The second caution that Dreyer warns against is how the metaphorical approach relates to epistemology. Is the truth of the narrative absolute and autonomous or does the truth lie beyond the experience as narrated by the participants? From a theological point of view, what is the role of God's narrative? The third critique of Dreyer relates to the methodological impoverishment by the limited use of commonly used quantitative and quantitative research methods (2014:7). This critique is an extension of the neglect of the marginalised groups and those at the periphery, who use narrative as "an audience to tell their stories". This is neglected within practical theology 
(Ganzevoort 2012:214). Feminist and womanist theology (Carol Christ), liberation theology (Gustavo Guiterrez), and black theology (James Cone) usually connect personal stories and praxis with Scripture and classical interpretations. Marginalised groups find the space to tell their stories to an audience that might consist of dominant and powerful groups.

\section{An open-narrative approach}

A narrative approach to practical theology is informed by the social, political, and religious challenges of the late twentieth century, such as the quest for diverse meanings amongst universalism, the meaning of personhood for identity, the tension between social construction and naturalism, the re-emergence of tradition and resurgence of context and experience. A narrative approach derives from critical engagement with traditional systematic theology and confronts the classical role of abstraction (abstract reason or discursive arguments) for theological engagement. This approach was influenced by modernity's project of reason, principle, individualism, and universalism. A narrative approach also countered the notion of reality that separates truth from meaning.

A narrative approach to practical theology is more reflexive and situational embedded in epistemology. Knowledge is not abstract, but has meaning and is meaning making within cultural and linguistic communities. Reality is socially constructed and truth is understood at the meeting point between object and subject. Abstract reason has little place within a narrative approach to practical theology and its privileged position is replaced by experience embedded reasoning.

My first attempt to investigate narrative for theological reflection was my doctoral thesis at the turn of the twenty-first century. In this research, I drew on the use of story by Geoffrey Wainwright, Stanley Hauerwas, Desmond Tutu, William Everett, Robin Gill, and Stephen Sykes. I investigated what the commonalities are in the way that narrative is used for moral formation. In this research, I identified reason, community, and particularity as commonalities amongst the approaches of the scholars. However, the three common dimensions are used in a fragmented manner. In 2012 I followed the doctoral studies up with an article that drew upon the three commonalities in what was to become my first attempt to formulate 
my approach of narrative for theology. My approach is termed openended narrative and "uses reason as critical engagement with community, particular and history” (Klaasen 2012:113).

I soon realised that an open-ended narrative approach that has reason, particularity, history, and community as the pillars of theological engagement has a serious limitation. That limitation is the neglect of experience as a tool for theological reflection in times of transition. In 2014 I analysed and critiqued Browning's influential approach to relate theory and practice. "The correlation of theory and practice refers to the emergence of the importance of theory and practice, and is presented as an interrelated relationship of practice, theory and practice" (Klaasen 2014:1). I discovered that despite the influence of Browning's critical correlational approach, the way that reasoning has been used reduced practical theology to professionalism and principles for ministry in the church and the world. This results in an antagonistic relationship between theory and the practice (Klaasen 2014:1). In view of this limitations, I have formulated a critical engaged practical reasoning approach for practical theology. Reason becomes engaged reasoning. Engaged reasoning is not technical or abstract reason, but enters in a relationship with experiences, as a tool of interpretation. My evolving approach of narrative for theological reflection now includes reason, community, tradition, and particular experience.

In 2015 and 2016 I attempted to apply an open-ended narrative approach to identity making. By applying open-ended narrative, I gave more attention to the form and structure of narrative. I concluded that open-ended narrative "invites critical engagement and dialogue on the experience of the affected people in relation to Transcendence or God. Identity, from the perspective of an open-ended narrative, is more than the sum of my story. It includes other stories in which I am one of the characters, yet not an irrelevant one" (Klaasen 2016:3).

The Christian faith assumes that identity is meaningful within the contours of the narrative, specifically the story of the person of Jesus Christ. It is a story of Jesus's birth, ministry, death, and resurrection. The story of Jesus Christ is not a closed story that is limited to our interpretation or the interpretation of any tradition. It is a story that is connected to the story of the Israelites and that of the Christian Church. It is a story that encapsulates the past, present, and future. The Christian story as open- 
ended is not closed to other stories, such as the story of culture or society. The understanding of the story of Jesus Christ is made clearer through interdisciplinary modes of interpretation.

The language of the Christian story is not restricted to a specific language or closed symbols. Language is not about disembodied rules or parts of the whole, but it is symbolic (non-rational) and speaks with the reason of the heart (Klaasen 2012:114). With regard to symbols, Gill claims that they are a tool of hermeneutics because it questions the perceived reality of the 'in-group'. Symbols also invite participation and transforms the enclave of both groups into what it means to be created in the image of God (1996:126128). Symbols uncover the plot of the story, which for both Lucie-Smith (2007:193) and Conradie (2008:27), "has cosmic significance" (Klaasen 2015:8). Narrative is not restricted to the writing or narrated modes of plots or dramas, but the story is the identity of a person(s). To tell a narrative of a person is not just transmitting information, as powerful as that may be, but is a mode of being in the presence of others; the telling of a story is living life in the company of others. It is a way of being before it is a mode of giving. The story is integral to the identity of the person. The story is not only information about the person, nor is it antagonistic with confessional forms of theology. The story is also not an intermediary or source of raw material. The structure and form of the story is lived experiences. This has left me with the question: What is the relationship between reason and experience?

\section{Experience embedded reasoning}

In an attempt to enhance Browning's practical reasoning, I have formulated a critically engaged practical reasoning approach with four stages. The four stage approach gives a prominent place for experience and consists of experience, reason, experience, and reason. This approach, like Browning's practical reason and Müller's adopted (from Van Huyssteen) transversal rationality, fails to narrow the gap between experience and reason. The result is that experience is reduced to a subordinate of reason.

Experience embedded reasoning, as opposed to critically engage reasoning, contends that rationality is embedded in experience and the two form part of the same interactionist process. Reason is socially constructed, but it 
also moves beyond the boundaries of social construction. Reason also influences experiences. Such reasoning is not abstract intellectual activities, but is situated within the experiences of all affected persons. Those who tell the story and those who hear and interpret or re-interpret the story have equal authority in meaning making. The meaning of the story is not left to the academic theologian who applies hermeneutics; the telling of the story has intrinsic value and meaning forms part of the narration.

Experience embedded reason, like Browning's practical reason or Müller's postfoundationalist transversal rationality, is not abstract reason. There is very little distance between the subject and object. The person(s) telling the story does not become an autonomous individual who simply observes and make individual sense of the story. The person is becoming, forming, and is constantly aware of the experiential dimension of reasoning.

The person stands in a tradition that is not static, but dynamic. Lucie-Smith refers to tradition as, "the shared language that makes communication possible, or more accurately it is the shared understanding of language that makes communication possible. Because words take their meaning from context and from the way they are used historically, a particular tradition can be understood then as the shared cultural understanding that binds a community together' (2007:4).

Tradition connects persons from different periods together and makes communication possible. Unlike the modern project that takes disembodied rules as a part of the whole, tradition takes the symbolic and metaphorical nature of communication seriously (Klaasen 2012:113-114). Instead of the narrow space that universal principles and rules create, tradition is like "an open work of art" (Ganzevoort 2012:219) that creates the space for my story to find expression and meaning within the story of God.

Müller's postfoundationalist or transversal narrative approach to practical theology is more towards collectivism than community. Collectivism refers to the co-operation for common goals. Here, the individual has meaning apart from that which is outside of the self. Community has a more prominent position than co-operation in an open-ended approach to practical theology. The self finds meaning outside of itself. The 'other' is not a disengaged commodity, but a constructed other that interacts with the openness to be formed and to form. 
Community does not dominate the person as in the dominant African philosophical notion of personhood. Within the dominant African notion of person, the self is dependent on the community for its development into a person. Experience embedded reasoning values contextual and personal experience as fundamental for being a person. Person and community interact interdependently in a creative tension.

Experience embedded reason engages with experience not in general terms, but rather as contextual experience. The experience of the narrator should not be taken out of context, but the meaning of the experience is best interpreted when the context is considered as integral to the experience. Principles and rules generalise experience and subsequently, derive meaning from generalisations that give preference to universalism. Contextual experience, which is a breakaway from Browning and Muller, is authentic and the starting point of reasoning. Where Browning consumes experience into theory and Müller separates experience from rationality, experience embedded reason considers the context of the story to be both part of the form and content of the story.

Contextualexperienceis notrestricted to relativism, but forms the foundation (without enslavement by foundationalism or postfoundationalism) of engagement beyond the current experience. Contextual experience draws from Fletcher's Situation ethics, which guards against reducing the human experience to commonalities through doctrines, creeds, principles, and rules. ${ }^{10}$

\section{Conclusion}

Narrative approach to practical theology has its roots away from traditional approaches to systematic theology. Discursive arguments and abstract reason as the only way to interpret reality and discover truth are challenged. The role of tradition and community for meaning making are considered indispensable. More importantly, experience is given a more primary position than reason.

10 For a detailed discussion of this point, see Goldberg (1981:20-24). 


\section{Bibliography}

Cone, J 1975. God of the oppressed. New York: Seabury Press.

Conradie, E. 'The earth in God's economy: Reflections on the narrative of God's work', Scriptura 97, (2008), 13-36.

Dreyer, JS 2014, 'The narrative turn in practical theology: A discussion of Julian Muller's turn in practical theology: A discussion of Julian Muller's narrative approach', Verbum et Ecclesia 35(2), Art. \#889, 9 pages.

Ganzevoort, RR 2012 'narrative approaches' in Miller-McLemore, B.J. (ED.), The Wiley-Blackwell companion to Practical Theology, pp. 214-223, West Sussex: John Wiley and Sons, Ltd Publication.

Gill, R (ed.), 1996. Theology and sociology: A reader. Edinburgh: T and T Clark.

Goldberg, M 1981. Theology and Narrative: A critical introduction. Abingdon: Nashville.

Hunsinger, G and Placher, WC (eds.) 1993. Theology and Narrative: Hans W. Frei Selected essays. New York: Oxford University Press.

Klaasen, JS 2012, 'Open-ended narrative and moral formation', Acta Theologica 32 (2), 103-124.

Klaasen, JS 2014, 'Practical theology: A critically engaged practical reason approach of practice, theory, practice and theory', HTS Teologiese Studies/Theological Studies 70(2), Art. 1950, 6 pages.

Klaasen, JS 2015, 'The missionary role of mainstream Christianity:

Towards a narrative paradigm for social integration of minorities in pluralistic post-apartheid South Africa', HTS Teologiese Studies/ Theological Studies 71(2), Art. \#2115, 9 pages.

Klaasen, J 2016. 'Identity, race and faith: The role of faith in postApartheid South Africa', HTS Teologiese Studies/Theological Studies 72(2), a3861. [Online] Available: http://dx.doi.org/10.4102/hts.v72i2.3861

Lucie-Smith, A 2007. Narrative theology and Moral theology: The infinite horizon. Burlington: Ashgate Publishing Company. 
Müller, J 2004. 'HIV/AIDS, narrative practical theology, and postfoundationalism: The emergence of a new story', HTS Teologiese Studies/Theological Studies 60(1\&2).

Müller, J 2011, 'Postfoundational practical theology for a time of transition', HTS Teologiese Studies/Theological Studies 67(1), Art. \#837, 5 pages.

Müller, J, 'Practical theology as part of the landscape of Social sciences and Humanities-A transversal perspective', HTS Teologiese Studies/ Theological Studies 69(2), Art. \#1299, 5 pages.

O’Donnell, K 2003. Postmodern. England: Lion.

Park, S-K 2010. 'A postfoundationalist research paradigm of practical theology', HTS Teologiese Studies/Theological Studies 66(2), Art. \#849, 6 pages.

Parsons, S 1996. Feminism and Christian ethics. Cambridge: Cambridge University Press.

Reyneke, J 2005. 'A practical theological narrative research of the adaption process of a family that moved from South Africa to New Zealand', In die Skriflig 39(4), 773-792.

Smith, D, Hofmeyr, M, Kritzinger, K and Saayman, W 1990. Wit Afrikane? In gesprek met Nico Smith. Bramley: Taurus.

Stroup, GW 1981. The promise of narrative theology. London: SCM Press. 